\title{
Acute abdomen due to torsion of the wandering spleen: A rare clinical presentation
}

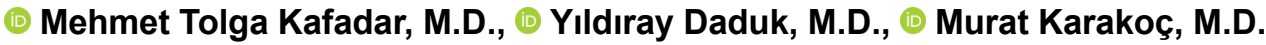

Department of General Surgery, Health Sciences University Mehmet Akif Inan Training and Research Hospital, Şanlıurfa-Turkey

\begin{abstract}
Wandering spleen is defined as the spleen that is not in its normal anatomic position due to the absence or laxity of suspensory ligaments. Congenital and acquired factors play a role in its etiology. It is a rare condition and may cause life-threatening complications as torsion or infarction. Rarely, patients may present to the emergency department with an acute abdomen. They may also present with chronic abdominal pain or intraabdominal mass. Given that its clinical diagnosis is difficult to make, radiological studies have an important role for an accurate diagnosis. In this paper, we presented a 24-year-old patient with torsion of a wandering spleen who presented with an acute abdomen and underwent laparoscopic splenectomy under urgent conditions.
\end{abstract}

Keywords: Acute abdomen; laparoscopic splenectomy; wandering spleen.

\section{INTRODUCTION}

Wandering spleen results from laxity or complete absence of splenocolic, splenorenal, and gastrosplenic ligaments that provide stabilization of the spleen. Having a long pedicle, the spleen freely moves inside the abdomen and may cause an acute abdomen with the torsion of the vascular pedicle. ${ }^{[1]}$ The disease may be treated with surgery. Splenopexy is the usual option when there is no torsion or the vascular supply of the spleen returns to normal after detorsion of the spleen. Splenectomy is the only option for a torsioned spleen with irreversible derangement of the vascular supply, as well as in cases with splenic areas of infarction or thrombi. ${ }^{[2]}$ In this paper, we aimed to report a rare case of wandering spleen torsion that presented with an acute abdomen.

\section{CASE REPORT}

A 24-year-old woman presented to our emergency department with abdominal pain that had started three days before her admission. On physical examination, she had diffuse abdominal tenderness, guarding, rebound tenderness, and paraumbilical fullness. She had no history of comorbidities. She had previously presented to a hematology clinic for clarification of splenomegaly but received no diagnosis. Laboratory tests results revealed white blood cell count: $7200 / \mathrm{mm}^{3}$, hemoglobin: $9.8 \mathrm{~g} / \mathrm{dL}$, platelet count: $349000 / \mu \mathrm{L}$, C-reactive protein: $44.5 \mathrm{mg} / \mathrm{dL}$, international normalized ratio: 0.95 (range, 0.8-1.2), prothrombin time: $12.9 \mathrm{~s}$ (normal range, 10.5-15.5 s), activated partial thromboplastin time: $22.4 \mathrm{~s}$ (normal range, 22-36 s); other biochemical parameters were normal. Whole abdomen ultrasonography (USG) revealed that the spleen with increased size $(18 \mathrm{~cm})$ was located at the infra-umbilical area at the midline; there was no flow in the splenic vein; there was also free fluid in the pelvis. A contrast-enhanced abdominal tomography (CT) showed that the splenic vascular structures coiled like a swirl and twisted with signs of torsion; there was no contrast filling of the vascular structures at the level of splenic hilus; there was also pelvic free fluid (Fig. Ia-d). The patient was urgently taken to the operating room. Abdominal exploration revealed that the spleen descended down to the pelvis, that the splenic artery and vein twisted around their axes, and that the spleen was

Cite this article as: Kafadar MT, Daduk Y, Karakoç M. Acute abdomen due to torsion of the wandering spleen: A rare clinical presentation. Ulus Travma Acil Cerrahi Derg 2021;27:154-156.

Address for correspondence: Mehmet Tolga Kafadar, M.D.

Sağlık Bilimleri Üniversitesi Mehmet Akif İnan Eğitim ve Araştırma Hastanesi, Genel Cerrahi Kliniği, Şanlıurfa, Turkey

Tel: +90414 - 3186000 E-mail: drtolgakafadar@hotmail.com

Ulus Travma Acil Cerrahi Derg 202I;27(I):I54-156 DOI: 10.14744/tjtes.2020.00734 Submitted: 06.12.2019 Accepted: 10.01.2020 Online: I4.12.2020

Copyright 2021 Turkish Association of Trauma and Emergency Surgery 
large and ischemic and contained patchy areas of necrosis (Fig. 2a). Given that the patient had signs and symptoms of acute abdomen, splenectomy was planned and laparoscopic splenectomy was performed using four ports and a single drain was placed (Fig. 2b). Pneumococcal, meningococcal, and influenza vaccinations were administered during the postoperative period. Having experienced no complication postoperatively, the patient was discharged with full recovery on the fourth-day of the post-splenectomy (Fig. 2c), and she suffered no problem in the first month of recovery. Written informed consent was obtained from the patient who participated in this case.

\section{DISCUSSION}

Wandering spleen was first defined by Van Horne in 1667 , and a case of wandering spleen that resulted in torsion was reported in 1885. ${ }^{3]}$ The prevalence of wandering spleen and splenic infarction is less than $0.2 \%$. Despite being more common in women, that ratio increases at the ages of 20 and 40 years. The spleen is an organ located beneath the left diaphragm in its normal anatomic position, which is anchored to adjacent organs and posterior abdominal wall by the splenocolic, splenorenal and gastrosplenic ligaments. Wandering spleen is defined as the spleen is out of its normal anatomic position due to the absence or laxity of those suspensory ligaments. ${ }^{[4]}$ Wandering spleen is usually located in the pelvis by the effect of gravity. Torsion may ensue when the spleen changes its location. The acquired factors that may lead to wandering spleen have been reported as splenomegaly, trauma, history of abdominal surgery, and muscular atrophies. ${ }^{[5]}$
Wandering spleen cases may be asymptomatic unless splenic torsion takes place. Laboratory tests are usually nonspecific, but an increase in inflammatory parameters or signs and symptoms related to hypersplenism or functional asplenia may occur. Chronic abdominal pain and thrombocytopenia may also occur. ${ }^{[3]}$ It is diagnosed by palpation of a pelvic mass or incidentally using USG, CT, or Magnetic Resonance Imaging (MRI). Patients with splenic torsion may present with abdominal pain, leukocytosis, nausea, vomiting, and signs of peritoneal irritation. Gastric outlet obstruction, obstructive uropathy, duodenal obstruction and portal hypertension may occur due to compression of adjacent organs. ${ }^{[6]}$

Diagnosis can be made by plain films, barium X-Rays, grayscale USG, scintigraphy, Doppler USG, CT, angiography. X-Ray studies with barium may show the displacement of intestinal loops due to splenic compression. Ultrasonography can clearly show splenic vascular supply, localization, blood flow in splenic artery and vein, and thrombi. Computed tomography is diagnostic by showing the absence of the spleen in its normal position but another abdominal region, usually in the pelvis. Contrast-enhanced tomography may give an idea about tissue viability and supply. Angiography may provide precise information about the vascular supply of the spleen, but it is more expensive, complicated, and time-consuming. ${ }^{[7,8]}$

Wandering spleen is treated surgically. When there is no torsion or splenic circulation is normal after detorsion, then splenopexy can be performed. Splenectomy remains the sole option in cases with splenic torsion with irreversibly damaged vascular supply or when there is splenic infarct or thrombi in the splenic artery and vein. ${ }^{[9]}$ We performed splenectomy
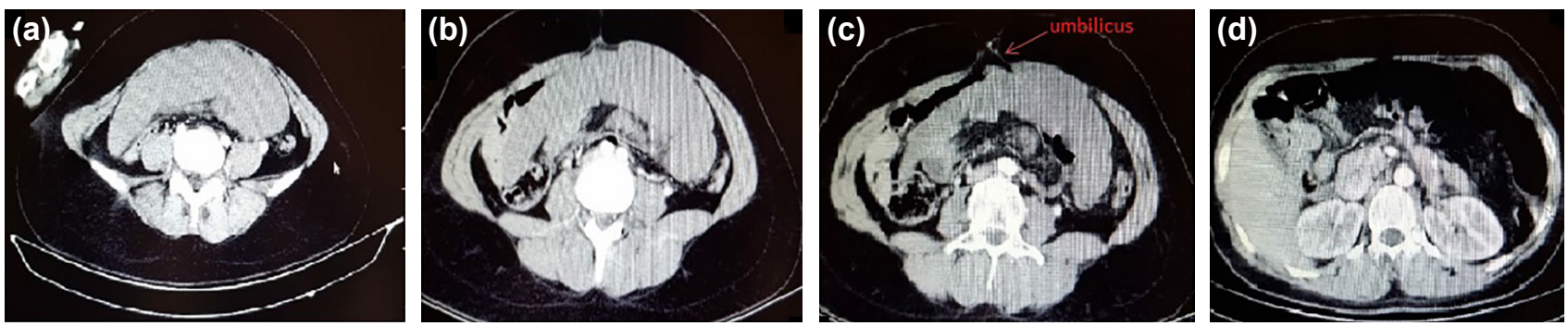

Figure 1. Preoperative tomographic images of the patient (a-d).
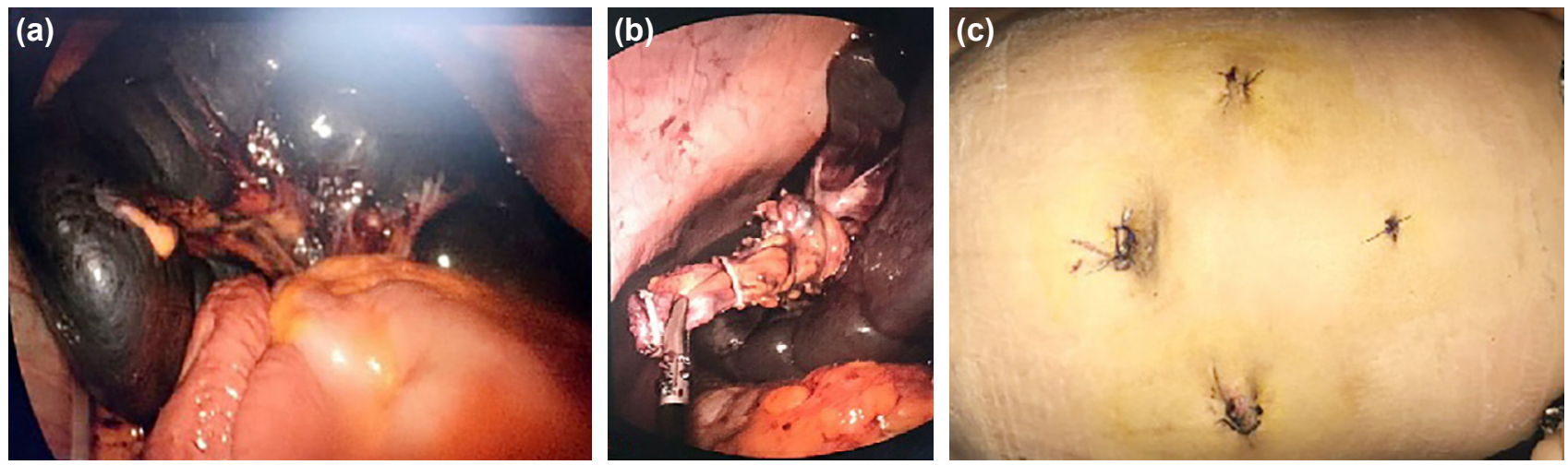

Figure 2. Intraoperative appearance of the patient $(\mathbf{a}, \mathbf{b})$, the postoperative appearance of the patient (c). 
as our patient had acute abdomen and splenic infarct zones. The laparoscopic technique can also be successfully used for the treatment of wandering spleen. There are many papers in the literature that report successful treatment of torsion of wandering spleen with the laparoscopic technique. ${ }^{[10]}$

\section{Conclusion}

Torsion of a wandering spleen should be remembered for differential diagnosis among patients with an acute abdomen and a palpable abdominal mass. It should never be forgotten that splenic torsion is a cause of an acute abdomen. Surgical methods employing splenic salvage should be preferred for patients without splenic infarcts, especially for the young patients.

Informed Consent: Written informed consent was obtained from the patient for the publication of the case report and the accompanying images.

Peer-review: Internally peer-reviewed.

Authorship Contributions: Concept: M.T.K.; Design: M.T.K., Y.D.; Supervision: M.T.K., M.K.; Materials: M.T.K., Y.D., M.K.; Data: Y.D.; Analysis: M.T.K., M.K.; Literature search: M.T.K.; Writing: M.T.K.; Critical revision: M.T.K.

Conflict of Interest: None declared.

Financial Disclosure: The authors declared that this study has received no financial support.

\section{REFERENCES}

1. Jude NN, Onochie NC. Torsion of a wandering spleen. A rare cause of acute abdomen. Saudi Med J 2015;36:1490-2. [CrossRef]

2. Moran JC, Shah U, Singer JA. Spontaneous rupture of a wandering spleen: case report and literature review. Curr Surg 2003;60:310-2. [CrossRef]

3. Soleimani M, Mehrabi A, Kashfi A, Fonouni H, Büchler MW, Kraus TW. Surgical treatment of patients with wandering spleen: report of six cases with a review of the literature. Surg Today 2007;37:261-9. [CrossRef]

4. Faridi MS, Kumar A, Inam L, Shahid R. Wandering Spleen- A diagnostic Challenge: Case Report and Review of Literature. Malays J Med Sci 2014;21:57-60.

5. Chauhan NS, Kumar S. Torsion of a Wandering Spleen Presenting as Acute Abdomen. Pol J Radiol 2016;81:110-3. [CrossRef]

6. Cohen O, Baazov A, Samuk I, Schwarz M, Kravarusic D, Freud E. Emergencies in the Treatment of Wandering Spleen. Isr Med Assoc J 2018;20:354-7.

7. Danaci M, Belet U, Yalin T, Polat V, Nurol S, Selçuk MB. Power Doppler sonographic diagnosis of torsion in a wandering spleen.J Clin Ultrasound 2000;28:246-8. [CrossRef]

8. Ben Ely A, Zissin R, Copel L, et al. The wandering spleen: CT findings and possible pitfalls in diagnosis. Clin Radiol. 2006;61:954-8. [CrossRef]

9. Peitgen K, Majetschak M, Walz MK. Laparoscopic splenopexy by peritoneal and omental pouch construction for intermittent splenic torsion ("wandering spleen"). Surg Endosc 2001;15:413. [CrossRef]

10. Nastiti NA, Niam MS, Khoo PJ. Emergency laparoscopic splenectomy for torsion of wandering spleen in a geriatric patient: A case report. Int J Surg Case Rep 2019;61:91-5. [CrossRef]

\section{OLGU SUNUMU - ÖZET}

\section{Gezici dalak torsiyonuna bağlı oluşan akut karın: Nadir bir klinik prezentasyon}

Dr. Mehmet Tolga Kafadar, Dr. Yıldıray Daduk, Dr. Murat Karakoç

Sağlık Bilimleri Üniversitesi Mehmet Akif Inan Eğitim ve Araştırma Hastanesi, Genel Cerrahi Kliniği, Şanlıurfa

Gezici dalak, asıcı bağlarının yokluğu veya gevşekliği nedeniyle dalağın normal anatomik lokalizasyonunda olmaması şeklinde tanımlanmıştır. Doğuştan ve edinsel faktörler etiyolojide rol oynamaktadır. Nadir görülen bir durumdur ve torsiyon veya enfarktüs gibi hayatı tehdit eden komplikasyonlara yol açabilir. Nadiren hastalar akut karın tablosu ile de acile başvurabilirler. Kronik karın ağrısı veya karıniçi kitle ile prezente olabilir. Klinik tanısı genellikle zor olduğu için, radyolojik incelemeler tanıda oldukça önemli yer tutar. Bu yazıda, akut karın tablosu ile başvuran ve acil şartlarda laparoskopik splenektomi uyguladığımız, 24 yaşında gezici dalak torsiyonu olgusu sunuldu.

Anahtar sözcükler: Akut karın; gezici dalak; laparoskopik splenektomi. 